\title{
Interactions among Environmental Stresses: Introduction to the Colloquium
}

\author{
Larry R. Parsons \\ Fruit Crops Department, IFAS, University of Florida, Citrus Research and Education Center, 700 Experiment \\ Station Road, Lake Alfred, FL 33850
}

How do plants respond to environmental stress? From numerous studies, we know how many plants respond to individual stresses such as drought, freezes, heat, chilling, or salinity. The purpose of this colloquium is to discuss not only how plants respond to single stresses, but also to discuss a more difficult topic-how plants respond to interacting stresses. Plants are seldom exposed to an individual stress, but are often exposed simultaneously to multiple

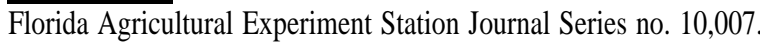

environmental stresses. For example, in Summer 1988, many plants in the Midwestern United States were exposed to both record drought and heat.

Whether the severe heat and drought of 1988 is evidence of the greenhouse effect is uncertain, but more scientists are accepting the idea that the earth is gradually warming. Global warming does not necessarily mean that winters will become milder. There is evidence suggesting that the earth's climate may be becoming more variable or erratic. Using an 89-year database, Karl et al. (1984) discussed 
an unprecedented period of abnormally variable winters during the 8 years of 1975-76 to 1982-83. During this period, three consecutive winters were much colder than average. Diaz (1984) indicated that the month of January during each of the seven winter seasons between 1975-76 and 1981-82 was well below average in much of the United States, particularly in the east. Freezes that brought just a few nights of severely cold temperatures killed $\approx 90,400$ ha of Florida citrus trees in 1983 and 1985 (Parsons et al., 1986). Damage from those two freezes to citrus alone was estimated at more than $\$ 2$ billion and $\$ 472$ million, respectively. This estimate does not include the extensive damage that also occurred to vegetables and ornamental.

Stress is often detrimental, but sometimes one stress can help the plant better-tolerate another stress. An example of this compensation is the complex interaction of water stress and freeze stress tolerance. Mild water stress can promote greater cold hardiness in citrus (Yelenosky, 1978, 1979), red osier dogwood (Chen et al., 1975), and other plants. Apparently, mild short-term dessication hardens the plant somewhat so it can withstand other stresses better. In red osier dogwood, short photoperiods and low temperatures decrease root conductance to water, which corresponds with a decrease in plant water content (McKenzie et al., 1974; Parsons, 1978). Hence, evolution appears to have developed some species with mechanisms that help reduce tissue water content as winter approaches.

In discussing interactions, among environmental stress, contradictions will appear. This condition is to be expected, because we do not yet know very much about stress interactions. For example, even though we know that mild water stress can temporarily promote cold hardiness, field evidence from Koo (1981) showed that citrus trees on irrigated plots survived freezes better than those on nonirrigated plots. Layne and Tan (1984) also showed that irrigation improved cold tolerance of peach trees, and nonirrigated trees were less able to withstand winter injury. These results would indicate that trees under longer-term water stress were somewhat weakened and thus less able to withstand the additional cold stress of winter than those stressed only mildly. Duration and severity of water stress can determine whether cold hardiness is increased or decreased. This apparent contradiction between short-term greenhouse tests and longer-term field irrigation studies has several possible explanations. A tree weakened by long-term water stress is less cold-hardy. In evergreen citrus, the nonirrigated trees possibly had a thinner canopy or were smaller. Heat can be lost from a grove more readily from trees with a thin canopy than those with a dense canopy. Hence, the level or extent of one earlier stress can affect the plant's response to a second stress.

Another factor is the duration of stress and plant response when stress is relieved. Low temperatures can promote cold hardening, but a warm period in winter can reduce hardiness levels. A week of warm weather can deharden deciduous tree fruit buds or citrus trees and make them susceptible to a later frost. Bud hardiness can decrease noticeably faster than it increases. Cherry fruit bud hardiness increased at rates of up to $0.12 \mathrm{C} / \mathrm{hr}(2.8 \mathrm{C} /$ day $)$, while hardiness was lost at rates of $0.6 \mathrm{C}$ to $1.6 \mathrm{C} / \mathrm{hr}$ (Proebsting and Mills,
1972). In red osier dogwood, relieving water stress by watering the plants can reduce hardiness levels in $\approx 7$ days (Parsons and $\mathrm{Li}$, 1979). Hence, while resistance to one stress (cold) may be temporarily enhanced by imposition of another stress (drought), levels of hardiness can change rapidly when one of the stresses is altered.

As studies on stress physiology develop in the future, a knowledge of interactions among stresses will become increasingly important. The purpose of this colloquium is to bring together ideas, give examples, and discuss how plants respond to the multiple stresses they encounter. For instance, we know that several of these stresses affect abscisic acid or proline levels. We hope to increase the awareness of how several physiological processes may change with stress. Both whole-plant and cellular aspects of stress interaction will be examined in this colloquium. In this way, we hope to develop a better integration of ideas. Topics will include important areas of stress interaction, such as the role of turgor, hormonal aspects, light and temperature, and cellular and membrane responses. This multistress view will become an area of greater research activity in the future and we hope that this colloquium will establish a beginning in synthesizing present areas of stress specialization. By addressing aspects of multiple stresses, we will be better able to predict how plants will respond to multiple environmental factors in the field.

\section{Literature Cited}

Chen, P., P.H. Li, and C.J. Weiser. 1975. Induction of frost hardiness in red osier dogwood stems by water stress. HortScience 10:372-374.

Diaz, H.F. 1984. The role of January in the character of recent winters in the United States. J. Climate \& Applied Meterol. 23:177.

Karl, T.R., R.E. Livesey, and E.S. Epstein. 1984. Recent unusual mean winter temperatures across the contiguous United States. Bul. Amer. Meteorol. Soc. 65(12):1302-1309.

Koo, R.C.J. 1981. The effect of fall irrigation on freeze damage to citrus. Proc. Fla. State Hort. Soc. 94:37-39.

Layne, R.E.C. and C.S. Tan. 1984. Long-term influence of irrigation and tree density on growth, survival, and production of peach. J. Amer. Soc. Hort. Sci. 109(6):795-799.

McKenzie, J.S., C.J. Weiser, and P.H. Li. 1974. Changes in water relations of Cornus stolonifera during cold acclimation. J. Amer. Soc. Hort. Sci. 99:223-228.

Parsons, L.R. 1978. Water relations, stomatal behavior, and root conductivity of red osier dogwood during acclimation to freezing temperatures. Plant Physiol. 62:64-70.

Parsons, L.R. and P.H. Li. 1979. Changes in frost hardiness of stem cortical tissues of Cornus stolonifera Michx. after recovery from water stress. Plant Physiol. 64:351-353.

Parsons, L.R., T.A. Wheaton, and D.P.H. Tucker. 1986. Floridafreezes and the role of water in citrus cold protection. HortScience 21(1):2, 175.

Proebsting, E.L. and H.H. Mills. 1972. A comparison of hardiness responses in fruit buds of 'Bing' cherry and 'Elberta' peach. J. Amer. Soc. Hort. Sci. 97(6):802-806.

Yelenosky, G. 1978. The effect of withholding water on cold hardiness of 'Valencia' orange and 'Star Ruby' grapefruit. trees in controlled freezes. Proc. Fla. State Hort. Soc. 91:18-20.

Yelenosky, G. 1979. Water-stress-induced cold hardening of young citrus trees. J. Amer. Soc. Hort. Sci. 104:270-273. 